\title{
Islamic Education Teacher Management in Implementing Guidance and Counseling Programs in Developing Student Attitude
}

\author{
Nazori $^{1 *}$, Bukman Lian ${ }^{2}$, Mulyadi $^{2}$ \\ ${ }^{1}$ SMK Negeri 3 Kayuagung \\ ${ }^{2}$ Universitas PGRI Palembang \\ *Corresponding author. Email: nazori1971@gmail.com
}

\begin{abstract}
This study aims to identify and describe the management of the implementation of guidance and counseling programs in fostering student morals at Public Vocational School 3 Kayuagung. This research uses qualitative methods. Data collection was carried out by interview, observation and documentation. Data analysis in this study includes data analysis, namely: data reduction, data presentation, and conclusion drawing. From the results of the study it can be concluded that the role of Islamic religious education teachers in fostering student morals at Public Vocational School 3 Kayuagung has an active role. The students' morals are quite good at the school. Students have prayed five times a day, respecting their parents, teachers and fellow friends. Students also reflect good morals by saying greetings when meeting teachers, helping people in need, throwing garbage in their place, etc. However, there are still some students who sometimes practice bad morals, such as arriving late, making noise when studying, not greeting and making fun of friends.
\end{abstract}

Keywords: Management, Academic Qualifications, Quality of Education

\section{INTRODUCTION}

Science and technology continues to develop in Indonesia. The demands of society are increasingly complex and competition is also getting tougher, especially in the face of the era of globalization and free trade, for that it is necessary to prepare quality human resources, one of the efforts to improve human resources is through education. Education is one of the main factors for human resource development because education is believed to be able to increase human resources so that it can create productive humans who are able to advance their nation [1]

The aim of national education is based on [2] concerning the National Education System, as follows: National education aims to develop the potential of students to become human beings who believe and have faith in God Almighty, have noble character, are healthy, knowledgeable, capable, creative, independent and become democratic citizens as well as being responsible. The aim of education that the Indonesian government wants to achieve is to educate the nation's life. Therefore, the government has provided ample opportunities to obtain education for all Indonesian people. In his daily duties, the teacher is faced with a problem, that is, he has to give the same teaching to different students. The differences come from the cultural environment, social environment, gender and others.

The world of education tends to teach ethical, moral ways with others. One of them is an attitude that reflects compliance and obedience to rules that have been mutually agreed upon. This means discipline, which means obedience to rules or regulations such as arriving on time, participating in all activities and returning home on time. In addition, according to [3] states that the definition of discipline is an orderly state when people who are members of a system are happy to obey existing regulations without coercion from others (own awareness).

The development of science and technology, whose impact is felt in the ways and changes of human life, indicates that the challenges of human life in the future will be more complicated. Adaptation to various kinds of progress will result in increased demands and needs and bring various implications and side effects in human life. 
Facing these tendencies, individuals are required to be more creative in developing their potential so that they are able to become humans who master knowledge and technology, have high independent abilities, and are aware of high faith as well. Armed with such a quality framework, individuals will remain resilient in the midst of changes and challenges that have been, are, and will continue to be.

Efforts to realize human beings as mentioned above require the world of education which is conceptually an endeavor to help individuals develop their potential so that they pay attention to humanitarianism in an integrated manner in every educational activity.

The above frame of mind implies that school as a vehicle for the delivery of formal education is not only required to be a vehicle for the implementation of teaching which emphasizes the development of cognitive abilities. Coaching and personal development of students also need attention and service [4] Andthe complex 's her problem faced by young people today turned out to be not only handled through the learning process alone but requires special services that cannot be done through the teaching of the guidance and counseling services [5]. By realizing the importance of guidance and counseling in the educational process as a support for the success of the teaching and learning process, it is necessary to conduct upgrades for teachers on guidance and counseling, along with knowledge and approaches to be completed.

These approaches are of course based on an understanding and recognition of the mental life of adolescents and their personalities and their characteristics, as well as what factors easily influence the adolescent's life. In taking the approach, a teacher also needs to know what methods can be applied in an effort to help adolescents solve their personal and socio- economic problems.

As a guide or instructor, teachers also need to understand their duties and roles in the scope of guidance and counseling. Special among religious teachers madrassa or in institutions - institutions of religious education or in public schools expect every teacher or prospective teachers have basic knowledge and skills to serve as educators and counselors, considering the religious education is a process of influence and foster students to be human adults who are faithful and pious who are at the same time knowledgeable with personal integration and dedication, creative power and high achievement in their lives as good citizens [6].

It can also be said that the direction of religious education is to foster religious people who are able to carry out the teachings of Islam well and perfectly, so that it is reflected in attitudes and actions in life, in order to achieve world life and the hereafter.

Therefore, religious teaching is oriented towards practice, whether that practice is in the form of muamalatul ma'al khalaqi which will perfect the human relationship with God in the form of solemn worship, tawaduk and tawakal, muamalatul ma'al creatures that will perfect human relations with its various aspects, muamalatul ma 'an nafsi, namely the existence of balance, harmony, and harmony between the relationship between the two so that it is engraved in the person [7].For the above purposes, teachers or prospective religious teachers need to expand their studies in the field of youth today so that the tendencies and ideals or desires and psychological tendencies, environment and so on can be further recognized. It is through this guidance and counseling knowledge that teachers are expected to be able to develop attitudes and understanding among most teachers in schools that educating and teaching does not merely transfer knowledge (transfer of knowledge) to students [6].

But the teacher is also a muaddib, a person who tries to manifest good character or character or as a shaper of moral values (transfer of values) to students, as well as at the same time fostering and developing their individual and social character and abilities. This guidance needs to be extended beyond schools, in the community and in the family. For example: scouting activities, spirituality, arts and culture clubs, social activities, visits to student families and so on (Abdul, 2012: 42).

As for the fields of knowledge that need to be recognized by supervisors and extension agents are at least 1) Developmental Psychology (children, puberty, youth, religion), 2) Inner Psychology (passions, emotions, subconscious level and so on) ), 3) Pedagogic (theoretical education for childhood, adolescence as well as a philosophical view of human education development) ,4) Methods or approaches to the problem of psychological barriers in human life based on various disciplines , 5) The principles of mental health sciences , 6) Administrative guidance and counseling , 7) sciences are another relevant example: the principles of psychotherapy, psychiatry to avoid obstacles and psychiatric disorders in learning activities , [8]

Guidance and counseling officers at religious education institutions are required to know and practice their religious teachings and have the ability to approach religious patterns of students or adolescents which are their scope of [6]Guidance and counseling services should take place effectively to help students achieve their development goals and overcome problems, including guiding students to disciplined behavior. This causes the need for guidance and counseling services in addition to teaching activities. 
Adolescence is a time when students begin to look for their identity, habits that tend to lead to negative things such as promiscuity, unstable emotions, wanting to win alone, drinking alcohol, drugs, and so on.

Guidance is a process that must be passed by a number of individuals who need change or more positive self-development, guidance is carried out by a professional counselor in their field so that the guidance can run well and optimally.

According to Lefever in[9], guidance is part of an orderly and systematic educational process to help young people grow on their strength in determining and directing their own lives, so that in the end they can gain experiences that can make a meaningful contribution to Public.

So the guidance of Islamic religious teachers, which the author means, is the assistance provided by Islamic Education Teacher in the form of religious guidance with the intention of becoming a person who has a personality and acts in accordance with the teachings of his religion.

In management science, there are many opinions related to management that come from experts both from Indonesia and from abroad. The development of management is so rapid that it causes many definitions to be put forward with each other's point of view, but basically still has the same view that management is related to the ability to move people to achieve goals.

According to Georger R. Terry [10] state that, "Management is a distinctive process, which consists of actions, planning, organizing, activating and monitoring, which are carried out to determine and to achieve predetermined goals through utilization. human resources and other sources.

In Indonesian, the word Guru comes from the Sanskrit language which means a person who is digugu or someone whose opinion and words are followed. A teacher is a role model for his students so that every word he says is always imitated and every behavior and action becomes an example for his students.

Etymologically in the Islamic educational literature a teacher is commonly referred to as ustadz, mu`alim, murabbiy, murshid, mudarris, and mu`addib, which means that people provide knowledge with the aim of educating and developing students' morals to become people with good personalities [7],

Meanwhile, in terms of terminology, according to [7], the teacher is a person who is authorized and responsible for the education of students, both individually and classically. Both at school and outside of school.

In simple terms, the teacher is the one who memberik a $n$ science to students. Teachers in the view of society are people who carry out education in certain places, not necessarily in formal educational institutions, but can also be done in mosques, in prayer rooms / prayer rooms, at home and so on [11],

Guidance and counseling is a unity that comes from two words, namely guidance and counseling. Guidance and counseling activities are always carried out in schools to overcome students with problems.

Linguistically, the word morality is taken from Arabic, the plural form of the word "khuluqun" which means character, temperament, behavior or character. The word khuluqun is isim jamid versus isim musytaq. In terms of morals, it is a complete system consisting of the characteristics of reason or behavior that makes a person more special. More briefly about the definition of morals proposed by Hamid Yunus in Nasharuddin, namely: "morals iallah the qualities of educated humans".

Based on the linguistic point of view, Zahruddin and Sinaga in Zubaedi suggest that the definition of morality in the everyday sense is equated with "character", morality, courtesy, manners (Indonesian version) while in English it is equated with the term molal or ethic [12]

Thus, the word morality is a word that is used to describe human actions which are then measured whether a person is good or bad. And in Islam, the measure is used to judge good.

\section{METHODS}

From a methodological perspective, this research is a type of qualitative research. The qualitative approach in this research is descriptive. Descriptive research is research on current phenomena. The process carried out is collecting and compiling data, and analyzing and interpreting the data. In essence, qualitative descriptive research is a method of examining the status of a group of humans, an object with the aim of making a systematic, factual and accurate descriptive, picture or painting of the facts or phenomena being investigated.

This approach views that reality is a dimension that is plural, intact and also changing. So, research develops during the process which makes it possible to change the concept according to the existing situation and conditions. Then this research will produce a description of the observed symptoms which do not have to be numbers. data were collected using questionnaires, observation sheets, and interview guides.

\section{RESULTS AND DISCUSSION}

After concluding the results of observations, interviews and documentation that have been carried out by researchers, it can be concluded that the results of this 
study indicate that Islamic Religious Education teachers have played an active role in fostering student morals at Public Vocational School 3 Kayuagung. This can be seen from the various participation carried out by Islamic Education Teacher which aim to foster student morals. For example, the teacher provides exemplary, habituation, admonition and also acts as a leader, namely by inviting students for good.

This is very much in accordance with the duties and functions of a teacher, namely as a leader (managerial), who leads, controls himself, students and the community related to various problems relating to efforts to direct, organize, control and participate in educational programs carried out.

In addition, Islamic Education Teacher also carry out various methods so that character building for students is achieved very well. The method used is, example or role model, giving advice, habituation, and punishment. The method most often used by Islamic Education teachers is the example or exemplary method. This is shown by Islamic Education Teachers from their daily lives as teachers. In accordance with the competencies that must be possessed by every teacher, namely having noble morals and being able to be role models which include acting in accordance with religious norms (faith and taqwa, honest, sincere, helpful) and having behaviors that are emulated by students. By carrying out the duties, functions, and competencies that should be performed by an Islamic Education teacher, he also carries out various methods. So students also have morals in accordance with Islamic sharia. This can be seen from the daily lives of students who have carried out their obligations in accordance with the regulations required by the madrasah. besides that, the students have also carried out their obligations as kamil people.

As for the morals that waji b has by a student, namely:

1. Morals towards Allah SWT

2. Morals towards Rasulullah SAW

3. Personal morals

4. Morals in the family. Namely consisting of; reciprocal obligations between parents and children, obligations of husband and wife, and obligations towards relatives.

5. Social morals. Namely consisting of; what is forbidden, what is ordered, and the principles of manners.

6. State morals. Namely consisting of; the relationship between leaders and people

Even so, it does not rule out that there are still students who often break the rules and act disgraceful or bad morals. Examples like, d a tang late, bullying each other friends, and so forth.

On this occasion the researcher also conducted observations in the classroom led by each teacher of Islamic religious education in turn. From the results of observations made by researchers for each Islamic Education teacher, all Islamic Education teachers generally carry out their duties according to the role that each Islamic Education teacher must perform. From the observations made by researchers, teachers of Islamic Religious Education at Public Vocational School 3 Kayuagung amounted to 3 people. Every time entering the class the teacher greets the students, then all students stand led by the class leader to greet the teacher, the teacher allows the students to sit down. Then the teacher checks the condition of the classroom and student rules, such as cleanliness, order, beauty, shade, health, kinship, security and religion that is applied by the teacher by reading prayers and short letters together before learning.

At the time of closing the lesson the teacher closes the lesson by reading Hamda accompanied by prayer together with the students. And then the teacher left the classroom to a safe state and men g say hello. In the last subject, after closing the lesson, the teacher stands in front of the class, all students stand led by the class leader, then the students greet the teacher, the teacher allows the students to sit down. Then the teacher left the classroom, and all the students prepared to go home. Apart from that, the teacher also provides good role models for students in the classroom when teaching. Namely by wearing polite, neat, disciplined, and authoritative clothes. There are also teachers who provide experiences to students by providing examples of stories related to the learning being discussed.

In this case the researcher made observations in the Public Vocational School 3 Kayuagung environment. Such as in the canteen or cafetaria, and prayer room. This school is built in a rectangular shape, where the main gate is on the side of the building, in the middle of the building is left empty which is used for parking and field locations.

The picket teacher is also responsible for checking students who do not comply with school regulations, such as wearing shoes, socks, long nails, long hair and others. Then the students entered their respective classes in an orderly manner. This rule is the same for students who enter during the day. The difference is, students who enter the morning do the morning roll in the school field before learning in their respective classes.

During the break schedule, students are allowed to buy food in the canteen and around the school building. Each istir a hat teachers picket and guard coordinate student / I was resting and buying food out of the building of the school, also pay attention to the student / I eat while standing. Apart from that, students who want to enter the classroom, the principal's office, the BK room, the teacher's room, and the administrative room are required to knock on the door first and say hello. Then when meeting teachers both on the street and 
in the school environment, they also greet the teacher. From observation results, it is applied to the student of Public Vocational School 3 Kayuagung in daily life.

Not all activities that are made in an institution or organization can run properly. That is, there must be certain obstacles and impulses or motivations that will hinder and encourage the achievement of a perfect goal. This is the same as moral building in students. The driving factors for Islamic Education teachers in developing student morals are as follows:

\section{1) Exemplary Teacher}

A teacher is a person who must be imitated. In accordance with the meaning of teacher according to Indonesian, namely the word Teacher comes from the Sanskrit language which means people who are digugu or people who are followed by their opinions and words. A teacher is a role model for his students so that every word is always imitated and every behavior and deed becomes an example for his students.

\section{2) Parents of Students}

Next is the influence of the parents of the students. The first educators of a child are the parents themselves. Then the parents take their children to get formal education, namely school or madrasah. At school, it does not mean that a teacher is fully responsible for a child's education, parents must also take part in guiding or nurturing him to become a noble human being.

Education or guidance at school must be balanced with parent education at home. Some parents carry out their obligations as parents by providing motivation and guidance to their children to be better. Such as agreeing to the rules made by the school, prohibiting children from bringing cellphones to school and wearing a headscarf even outside the school environment

\section{CONCLUSION}

Duties and responsibilities of Islamic Religious Education teachers. More than just tutoring, teachers must be able to provide moral and moral guidance and faith to their students. Therefore, the guidance and counseling function of Islamic Religious Education teachers is much heavier than teachers of other subjects. With regard to the role of subject teachers in counseling guidance, subject teachers in approaching students must be human and religious, friendly, friendly, encouraging, concrete, honest and genuine. Likewise, with Islamic Religious Education teachers, all the guidance and counseling provided by Islamic Religious Education teachers should be based on and based on the teachings of the Islamic Religion. The details of the roles, duties and responsibilities of subject teachers in guidance and counseling are to help promote guidance and counseling services to students, identify students who need guidance and counseling services, provide opportunities and convenience to students who need guidance and counseling services, help collection of information needed in the framework of assessing guidance and counseling services and follow-up efforts.

\section{REFERENCES}

[1] Kunaryo, H. (2010). Pengantar Pendidikan. Semarang: IKIP Semarang.

[2] Undang- Undang RI No 20 tahun 2003. Tentang Sistem Pendidikan Nasional. Bandung: Citra Utama.

[3] Mulyasa, E. (2010). Implementasi Kurikulum Tingkat Satuan Pendidikan. Bandung: Remaja Rosdakarya.

[4] Abdul, H. N. (2010). Menghias Diri Dengan Akhlak Terpuji, Yogyakarta: Pustaka Pelajar Offset.

[5] Sugiyo., \& Sugiarto. (2014). Administrasi dan Organisasi Bimbingan dan Konseling Sekolah, Semarang : IKIP Semarang Press.

[6] Arifin, M. (2015). Kapita Selekta Pendidikan Islam dan Umum. Jakarta: Bumi Aksara.

[7] Muhaimin. (2015). Pengembangan Kurikulum Pendidikan Agama Islam, Jakarta: Raja Grafindo Persada

[8] Mukhtar. (2012). Desain Pembelajaran PAI, Jakarta: CV. Misaka Galiza.

[9] Prayitno. (2013). Dasar-dasar Bimbingan dan Konseling. Jakarta: Rineka Cipta.

[10] Mulyono. (2018). Manajemen Administrasi \& Organisasi Pendidikan. Jakarta; Rineka Cipta.

[11] Djamarah, S. B. (2011). Guru dan Anak Didik dalam Interaksi Edukatif, Jakarta: Rineka Cipta.

[12] Zubaedi. (2013). Desain Pendidikan Karakter; Kompetensi dan Aplikasinya Dalam Lembaga pendidikan. Jakarta: Prenada Media Group. 